\title{
Sleep disorders in patients with multiple sclerosis
}

\author{
Zaburzenia snu u pacjentów ze stwardnieniem rozsianym
}

Karolina Katarelos ${ }^{1}$, Agnieszka Piechal ${ }^{1,2}$, Iwona Kurkowska-Jastrzębska ${ }^{1}$

\section{ABSTRACT}

Sleep disorders is a common problem that patients report to their doctor. They can accompany many mental and somatic disorders or be primary. There are many types of sleep disorders; most commonly, they are associated with problems with falling asleep and maintaining sleep continuity, or more complex disorders, such as parasomnias, breathing disorders and movement disorders associated with sleep. In the following work, we have focused on sleep problems in patients with multiple sclerosis (MS). These patients more often than healthy people of the same age complain about sleep disorders and these disorders increase with the progress of the disease and the appearance of other symptoms. Depressed mood, chronic fatigue, pain and urinary problems significantly affect the quality of sleep in patients with MS. On the other hand, excessive sleepiness and trouble with falling asleep intensify the feeling of fatigue, which is a major problem and impair cognitive functions. However, sleep-related symptoms are often overlooked during medical visits due to other symptoms of multiple sclerosis, especially those causing motor disability. The treatment of sleep disorders in patients with MS is based on basic methods used in the general population. In the treatment of sleep disorders in patients with multiple sclerosis, appropriate disease modifying therapy is also important.

\section{STRESZCZENIE}

Zaburzenia snu stanowią częsty problem, z którym pacjenci zgłaszają się do lekarza. Mogą one towarzyszyć wielu schorzeniom psychicznym i somatycznym lub mieć charakter pierwotny. Istnieje wiele rodzajów zaburzeń snu. Najczęściej mają one związek z zaburzeniem zasypiania i utrzymaniem ciągłości snu, a także 
z zaburzeniami bardziej złożonymi, jak np. parasomnie, zaburzenia oddychania i zaburzenia ruchowe związane ze snem. W poniższej pracy skoncentrowaliśmy się na zagadnieniu problemów ze snem u chorych na stwardnienie rozsiane (sclerosis multiplex, SM). Pacjenci ci częściej niż zdrowe osoby w podobnym wieku skarżą się na zaburzenia snu, a zaburzenia te zwiększają się jeszcze wraz z postępem choroby i pojawianiem się innych dolegliwości. Obniżony nastrój, przewlekłe zmęczenie, ból oraz problemy $\mathrm{z}$ oddawaniem moczu $\mathrm{w}$ istotny sposób wpływają na jakość snu u chorych z SM. Nadmierna

\section{Introduction}

Multiple sclerosis (MS) is a chronic inflammatory disease of the nervous system, characterised by the occurrence of neurological deficits resolving or progressing over time. The number of patients with MS is estimated at about 2.5 million people worldwide (Najafi et al. 2013). The highest prevalence of MS is in North America and Europe. The disease is most often manifested at the age of $20-40$ and affects twice as many women as men. It is one of the most important causes of disability in young people, mainly due to progressive motor disability, but also due to cognitive deficits, visual disturbances, balance disturbances and many other symptoms so far less associated with multiple sclerosis (Bishop and Rumrill 2015; Sakkas et al. 2019; Veauthier 2015).

Sleep disorders are one of the disorders accompanying MS. Sleep disorders are suggested to occur more frequently in the population of people with MS than in the general population (Morse and Kothare 2018; Sakkas et al. 2019; Veauthier 2015). According to studies conducted so far, sleep problems can affect up to 42 to $46 \%$ of patients. This means that they may occur up to four times more often in this group of patients than in the general population (Sakkas et al. 2019). The frequency of sleep disorders in patients with MS shows variability depending on the duration of the disease. In a study conducted by Vitkova et al. (2014), the patients with MS were divided into two groups depending on the duration of the disease (up to 5 years and over 5 years), and sleep disorders were compared. Sleep disorders were found to be more frequent in patients with longer duration of the disease (34.8\%vs. $51.2 \%)$, which also correlated with a higher EDSS score (Vitkova et al. 2014). This would indicate their secondary nature, depending on the additional deficits arising during the course of the disease. Sleep quality can be affected by complaints, such as increased fatigue, depressed mood, cognitive disorders, chronic pain, sexual and sphincter dysfunction (Bishop and Rumrill 2015; Braley and Boudreau 2016; Sakkas et al. 2019). Symptoms, such as the neurogenic bladder, chronic senność i kłopoty z zasypianiem nasilają natomiast uczucie zmęczenia (stanowiące duży problem) oraz upośledzają funkcje poznawcze. Dolegliwości związane ze snem bywają jednak często pomijane w czasie wizyt lekarskich - z uwagi na to, że na pierwszy plan wysuwają się inne objawy stwardnienia rozsianego, szczególnie te powodujące niepełnosprawność ruchową. W leczenie zaburzeń snu u chorych z SM wykorzystuje się podstawowe metody stosowane w populacji ogólnej. Ważna jest w ich wypadku także odpowiednia terapia modyfikująca przebieg choroby.

pain, spasticity or anxiety disorders, often associated with MS, can cause significant difficulty in initiation or maintenance of sleep (Braley and Chervin 2015).

\section{Classification of sleep disorders}

Sleep disorders can take different forms (Morse and Kothare 2018). Their exact classification is defined by the International Classification of Sleep Disorders (ICSD-3) (American Academy of Sleep Medicine 2014; Sateia 2014). This classification is presented in Table 1.

\section{Insomnia}

According to ICSD-3, insomnia can manifest itself in problems with sleep initiation, difficulty in maintaining sleep, or premature awakening (Najafi et al. 2013; Thorpy 2012). It is the most common manifestation of sleep disorders and represents about $90 \%$ of all sleep disorders. The American Academy of Sleep Medicine (AASM) has classified insomnia according to its duration. Short-term insomnia is insomnia lasting less than 3 months and chronic insomnia lasts more than 3 months.

According to the latest revision of the ICD-11 (International Classification of Diseases, 11th edition), insomnia is characterised by persistent difficulties with sleep initiation, incorrect sleep duration, consolidation or quality, and these difficulties occur despite adequate opportunity and circumstances to sleep and result in impairment of functioning during the day. Symptoms during the day usually include fatigue, depressed mood or irritability, general malaise and cognitive disorders. Persons who report sleep-related symptoms in the absence of impairment during the day are not considered insomniacs (World Health Organization 2018).

Table 2 presents the criteria for diagnosing insomnia according to DSM-V (American Psychiatric Association 2013).

Known risk factors of insomnia are older age, female gender, lower education, coexisting somatic and mental disorders (Wojtas and Ciszewski 2011). 
Table 1. International Classification of Sleep Disorders (ICSD-3), 2014; the table contains the most common disorders

\begin{tabular}{|ll}
\hline I. Insomnia & - Chronic insomnia \\
& - Short-term insomnia \\
- Other types of insomnia \\
II. Sleep-related & - Obstructive sleep apnoea \\
breathing & - Central sleep apnoea \\
disorders & - Sleep-related hypoventilation disorders \\
& - Sleep-related hypoxemia disorder \\
III. Central & - Narcolepsy type 1 \\
disorders of & - Narcolepsy type 2 \\
hypersomnolence & - Idiopathic hypersomnia \\
- Kleine-Levin syndrome \\
IV. Circadian & - Delayed sleep-wake phase disorder \\
rhythm sleep-wake & - Advanced sleep-wake phase disorder \\
disorders & - Irregular sleep-wake rhythm disorder \\
& - Non-24-hour sleep-wake rhythm disorder \\
- Shift work disorder \\
disorders
\end{tabular}

Table 2. Diagnostic criteria for insomnia according to DSM-V

\section{Diagnostic criteria:}

A. Complaints of dissatisfaction with sleep quantity or quality, associated with one (or more) of the following symptoms:

1. difficulties in initiating sleep (in children, this may manifest as difficulty initiating sleep without caregiver intervention)

2. difficulties in maintaining sleep, characterised by frequent awakenings or problems returning to sleep after awakenings (in children, this may manifest as difficulty returning to sleep without caregiver intervention)

3. Early-morning awakening with inability to return to sleep

B. Sleep disturbance causes clinically significant distress or impairment in social, occupational, educational, academic, behavioural, or other important areas of functioning.

C. The sleep difficulty occurs at least 3 nights per week

D. The sleep difficulty is present for at least 3 months

E. The sleep difficulty occurs despite adequate opportunity for sleep

F. The insomnia is not better explained by and does not occur exclusively during the course of another sleep-wake disorder (e.g., narcolepsy, a breathing-related sleep disorder, a circadian rhythm sleep-wake disorder, a parasomnia)

$\mathrm{G}$. The insomnia is not attributable to the effects of a substance (e.g. abused use of drugs, medications)

$\mathrm{H}$. Coexisting mental disorders and medical conditions do not adequately explain the predominant complaint of insomnia
No large-scale epidemiological studies assessing the incidence of insomnia in patients with MS have been performed so far. In smaller studies, it is estimated that it occurs in $40-50 \%$ of patients (Sakkas et al. 2019). In the study of Bøe et al. (2012), in which 90 patients with MS were examined, sleep disorders - based on the Pittsburgh Sleep Quality Index (PSQI) - were found in 67.1\% of participants. It turned out that sleep disorders in these patients were associated with pain, depression and fatigue and were more frequent in women and patients using immunotherapy. It was also shown that the most common manifestation of insomnia in patients with MS is difficulty with sleep initiation (Bøe et al. 2012).

Stanton et al. (2006) examined patients with MS for insomnia and its causes. The most common factors causing insomnia were anxiety, pain and depressed mood. The study revealed difficulties with sleep initiation in $42 \%$ of the 60 examined patients.

\section{Circadian Rhythm Sleep-Wake Disorders}

Circadian activity rhythm (CAR) is one of the most important mechanisms that affect the duration and quality of human sleep. Circadian rhythm is a cycle of changes in physiological processes, such as movement, rest, sleep, and eating during the day, which are regulated by a biological clock. The circadian biological clock is located in the hypothalamus part of the central nervous system in the suprachiasmatic nuclei. The work of the biological clock consists of rhythmically switching on and off transcriptions of so-called clock genes. The circadian rhythm is largely regulated by the melatonin secreted by the pineal gland. It affects the $\mathrm{MT}_{1}$ and $\mathrm{MT}_{2}$ receptors, which are found in many areas of the brain, including the suprachiasmatic nucleus, the hippocampus, the amygdaloid body, the cerebellum and other cells of the body such as the cells of the retina and pancreas (Skarlis and Anagnostouli 2019).

Currently, circadian activity rhythm dysfunction is increasingly being reported in the general population. This is largely due to lifestyle, including shift work, long hours of mental activity, little sports activity, irregular eating and little time spent outside and thus low exposure to sunlight. It has been proven that certain diseases can lead to a higher incidence of circadian rhythm disorder. Such a case is Alzheimer's disease, in which there is a reduction in the number of neurons of the suprachiasmatic nucleus, which leads to the loss of its function of regulating the circadian rhythm (Wichniak et al. 2017).

The issue of circadian rhythm disorders in patients with MS is not yet well researched; however, the interest of researchers in this topic is growing. It has been found that circadian rhythm-related regulatory genes, such as ARNTL and CLOCK, may be related to the incidence of MS. These genes show high variability and the occurrence of some genotypes may be a factor of increased risk of MS. In the studies conducted so far on the prevalence of 
CAR in patients with MS, conflicting results were obtained (Tonetti et al. 2019). The study by Taphoorn et al. (1993) did not show CAR dysfunction in patients with MS, while the study by Najafi et al. (2013) confirmed the higher incidence of CAR dysfunction in patients with MS. Recently in Bologna, Tonetti et al. (2019) studied 35 patients with MS. The criteria for inclusion in the study included: age 18-65, less than 2 years from the diagnosis of MS, therapy modulating the course of the disease over 6 months, no exacerbations and steroid therapy during the last month, no night shift work, no coexisting chronic and psychiatric diseases, no observed sleep disorders, no motor disorders, no use of psychoactive substances. The study was carried out with the use of an actigraph, a motor activity sensor used for continuous recording of 24-hour activity. The results of the study showed that the sleep duration of patients with MS compared to the control group, which were healthy people, was the same, but the sleep quality was slightly worse. Summarising these results, the researchers concluded that the impact of the disease at its early stage on CAR may be much smaller than when the disease is at a more advanced stage when patients are more likely to suffer from other factors predisposing sleep disorders, such as bladder sphincter dysfunction or restless legs syndrome (Tonetti et al. 2019).

In the context of CAR, it is worth mentioning that since the 1990s, scientists have been investigating the relationship between melatonin and the pathogenesis and the course of MS. In most of the studies conducted on this subject, a reduced concentration of melatonin in serum or its metabolites in urine was found in patients with MS. This may indicate the possible significance of its deficiency in the pathogenesis of MS. The correlation between the course of the disease and the concentration of melatonin in the blood remains so far unknown, and the studies carried out so far have produced contradictory data on the issue (Skarlis and Anagnostouli 2019). Damasceno et al. (2015) obtained results confirming the relationship between the reduced amount of melatonin metabolites in urine and the severity of fatigue, the number of disease exacerbations and higher scores in the Expanded Disability Status Scale (EDSS) in patients with MS. However, studies by Farhadi et al. (2014) and Gholipour et al. (2015) did not confirm the relationship between the reduced concentration of melatonin in serum and higher EDSS scores. Research is currently underway on the role of melatonin in MS therapy. These studies aim to assess whether the use of melatonin can have a possible impact on the course of the disease, as well as on sleep disorders or depression (Skarlis and Anagnostouli 2019).

\section{Restless legs syndrome}

One of the most frequent and extremely severe sleep-related ailments is restless legs syndrome (RLS). This syndrome consists of a strong urge to move one's lower limbs.
Symptoms occur most often in the evening or at night. The movement of the limbs is a relief. There are two forms of RLS - idiopathic and secondary. Idiopathic form occurs more frequently; it is likely to be hereditary as most patients report a family history of this disorder. It is also characterised by a higher incidence in women and its frequency increases with age. The secondary form is associated with iron deficiency, pregnancy and kidney failure. The association of a higher incidence of RLS in patients with myasthenia, coeliac disease, liver disease, rheumatoid arthritis, primary headaches or neuropathy has also been proven (Allen et al. 2013; Lee et al. 2013; Manconi et al. 2004; Sieminski et al. 2015). In the general population, the incidence of RLS is about 5\% (Gałecki and Szulc 2018).

The incidence of RLS is found to be higher in patients with MS. Depending on the different studies, the incidence was from $13.3 \%$ up to $65.1 \%$. The discrepancies were probably due to several aspects. Among other things, the similarity of RLS and MS symptoms - patients in both these conditions often report similar sensory symptoms: paraesthesia, such as numbness or burning, which, unless they show variability depending on the time of day, cannot be considered as a criterion for RLS diagnosis. Sieminski et al. (2015) analysed thirteen RLS and MS correlation studies conducted so far. In patients with multiple sclerosis, there was no evidence of a strong relationship of the female gender, family history and older age with a higher incidence of RLS. In only two of the analysed studies of patients with MS, a higher incidence of RLS in women was confirmed and patients with RLS were older than patients without RLS. Family history of RLS in patients with MS was confirmed in $2.4 \%$ to $27.1 \%$ of patients depending on the study. This is much lower than the idiopathic RLS (Sieminski et al. 2015). Some studies have also shown that patients with RLS have a higher EDSS score (Manconi et al. 2007; Sieminski et al. 2015). Some studies suggest that the original progressive form may be associated with a higher incidence of RLS than the other forms of SM (Sakkas et al. 2019).

Connor et al. (2011) performed an analysis of post-mortem myelin from the brain of patients with RLS and analysis of grey and white matter using voxel-based morphometry in the MRI of brains of patients with RLS. The study showed that patients with RLS have a reduced amount of myelin as well as a reduced amount of ferritin and transferrin in the myelin fraction, which indicates a reduced amount of iron in the brain of patients with RLS. This suggests that myelin damage may be related to the etiopathogenesis of RLS and thus MS may be a disease predisposing to this disorder.

\section{Sleep-related breathing disorders}

The most common form of sleep-disordered breathing (SDB) is obstructive sleep apnoea (OSA). OSA is a condition consisting of multiple episodes of apnoea during 
sleep significantly shallow breathing (Kuzminska 2011). In the general population, the prevalence of OSA is estimated, depending on the source, at $2 \%$ in women and $4 \%$ in men (Young et al. 1993) up to $5.7 \%$ in women and $12.4 \%$ in men (Simpson et al. 2013). Known risk factors for OSA are hypertension, diabetes, metabolic syndrome and depression (Simpson et al. 2013). The gold standard for diagnosis of OSA is polysomnography. The criteria for the diagnosis of OSA by polysomnography include, according to AASM, the occurrence of a minimum of 15 respiratory disturbances (RDI) in the form of apnoea, shallow breathing, and awakenings associated with respiratory effort, regardless of the presence of clinical symptoms $(\mathrm{RDI} \geq 15)$ or RDI $>5$ for individuals with at least one such symptom as 1) falling asleep against one's will, excessive daytime sleepiness, fatigue, insomnia, ineffective sleep; 2) awakening with the feeling of respiratory arrest, dyspnoea or choking; 3) loud snoring or apnoea detected by a person sleeping with a patient (Szczeklik and Gajewski 2019). As polysomnography is quite difficult to carry out in terms of logistics and quite expensive in case of a larger number of patients, questionnaires such as the Berlin and STOPBang questionnaires are also used, which inform about the risk of OSA (Simpson et al. 2013).

The prevalence of OSA in patients with MS - depending on the source - may reach up to $58 \%$. Table 3 presents a summary of studies on OSA in patients with MS. In a study conducted by Braley et al. (2014), the risk of OSA was assessed in patients with MS, $21 \%$ of whom had already been diagnosed with OSA. An increased risk of OSA was found in $56 \%$ of all respondents, based on the STOPBang questionnaire. In patients with OSA diagnosis, the risk assessed based on this questionnaire was $93 \%$.

There are also many indications that fatigue in the population of patients with MS may be strongly related to undiagnosed and untreated OSA (Braley et al. 2014; Kaminska et al. 2011). The gold standard of OSA treatment is the use of CPAP (Continuous Positive Airway Pressure) devices. One study showed a significant reduction in the feeling of fatigue and sleepiness during the day and an improvement in the quality of sleep in patients with MS using CPAP in this study (Cote et al. 2013; Kaminska et al. 2014).

The SDB group also includes central sleep apnoea (CSA). Breathing disorders in this condition result from impaired or interrupted nerve conduction or damage to the neuromuscular junction that innervates the muscles of respiration. CSA may be associated with vascular, neoplastic, degenerative, post-traumatic and demyelinating diseases of the brain stem (Plywaczewski et al. 2013). Patients with MS are at risk of central sleep apnoea due to the presence of demyelinating changes within the brain stem where the respiratory centre is located (Braley and Chervin 2015).

Table 3. Summary of studies on OSA and CSA in patients with MS

\begin{tabular}{|c|c|c|c|c|}
\hline Author & $\begin{array}{l}\text { Number } \\
\text { of patients }\end{array}$ & DMT & Method & Results \\
\hline Brass et al. (2014) & $n=2375$ & No data available. & $\begin{array}{l}\text { STOP-Bang questionnaire } \\
\text { Berlin Questionnaire }\end{array}$ & $\begin{array}{l}n=898 \\
37.8 \% \text { increased risk of OSA }\end{array}$ \\
\hline Braley et al. (2012) & $n=48$ & DMT at $69.75 \%$ & Polysomnography & $\begin{array}{l}n=27 \text { OSA } 56 \% \\
n=2 \text { CSA } 4,17 \% \\
n=3 \text { CSA and OSA } 6,25 \%\end{array}$ \\
\hline Sater et al. (2015) & $n=32$ & $\begin{array}{l}\text { Untreated, } \\
\text { planned for including DMT with } \\
\text { natalizumab }\end{array}$ & Polysomnography & $n=12$ OSA $37.5 \%$ of examined persons \\
\hline $\begin{array}{l}\text { Kaminska et al. } \\
\text { (2011) }\end{array}$ & $n=62$ & $\begin{array}{l}\text { DMT in } 69 \% n=43 \text { : glatiramer } \\
\text { acetate } n=20 ; \\
\text { interferon beta-1a } n=7 ; \\
\text { interferon beta-1b } n=8 ; \\
\text { cyclophosphamide } n=3 ; \\
\text { mitoxantrone } n=2 ; \text { natalizumab } \\
n=2 ; \text { fingolimod } n=1\end{array}$ & Polysomnography & $n=36 \mathrm{OSA}, 58 \%$ of examined persons \\
\hline $\begin{array}{l}\text { Čarnická et al. } \\
\text { (2015) }\end{array}$ & $n=50$ & No data available. & Polysomnography & $\begin{array}{l}n=11 \text { OSA, } 22 \% \text { of examined persons } \\
n=3 \text { CSA, } 6 \% \text { of examined persons }\end{array}$ \\
\hline $\begin{array}{l}\text { Tachibana et al. } \\
\text { (1994) }\end{array}$ & $n=28$ & No data available. & Polysomnography & $n=2 \mathrm{OSA}, 7.14 \%$ of examined persons \\
\hline $\begin{array}{l}\text { Veauthier et al. } \\
\text { (2011) }\end{array}$ & $n=66$ & No data available. & Polysomnography & $\begin{array}{l}n=6 \text { OSA, } 9.09 \% \text { of examined persons } \\
n=1 \text { CSA, } 1.52 \% \text { of examined persons }\end{array}$ \\
\hline Braley et al. (2014) & $n=195$ & $\begin{array}{l}\text { DMT at } 68.2 \% \text { : } \\
\text { beta-interferon } 31.3 \% \text {; } \\
\text { glatiramer acetate } 23.6 \% \text {; } \\
\text { natalizumab } 8.7 \% \text {; } \\
\text { other drugs } 4.1 \%\end{array}$ & STOP-Bang questionnaire & $\begin{array}{l}n=110,56 \% \text { of all examined persons } \\
\text { are at increased OSA risk } \\
n=41,21 \% \text { with previous OSA } \\
\text { diagnosis, based on STOP-Bang. } 93 \% \text { of } \\
\text { these patients are at increased OSA risk. }\end{array}$ \\
\hline
\end{tabular}

DMT - disease modifying therapy / therapy to modify the course of the disease 


\section{Factors affecting sleep in patients with MS}

\section{Mood disorders}

Depressed mood resulting from the disease itself and its progress predisposes to a higher incidence of depression in patients with MS. It is estimated that up to $50 \%$ of patients may suffer from depression (Braley and Chervin 2010). One of the basic symptoms of depression are sleep disorders, thus affective disorders require detailed diagnostics in patients with sleep disorders. An additional difficulty is that impaired sleep is both a risk factor and a symptom of depression. It has already been proven in numerous studies that patients with depression show changes in the EEG during sleep (Steiger and Pawlowski 2019). The Bøe et al. (2012) study on sleep disorders in patients with MS showed that among all patients taking part in the study, who were diagnosed with depression, sleep disorders were also found. This relationship is probably two-way - depression aggravates the symptoms of sleep disorders and sleep intensifies the symptoms of depression. Properly selected antidepressant treatment reduces sleep-related ailments.

\section{Pain}

Acute and chronic pain is a common symptom in MS and includes both neuropathic and musculoskeletal pain, secondary to other symptoms of MS, such as spasticity (Stenager et al. 1995). Population-based studies estimated that 55-65\% of patients with MS suffer from acute, subacute or chronic pain syndromes (Bøe et al. 2012; O'Connor et al. 2008). Chronic pain, not only in patients with MS, is a factor related to the quality of sleep, mainly with a sleep disorder. Among patients with MS, pain was much more common in people with sleep disorders than in those who sleep well (Bøe et al. 2012; Stanton et al. 2006). Regardless of gender and age, pain, poor pain management and depression are factors predisposing for sleep disorders (Vega et al. 2019). On the one hand, patients with MS do not differ in this respect from patients with other chronic pain syndromes. On the other hand, several large prospective studies suggest that sleep problems increase the risk of developing chronic pain in the future, and good sleep increases the chance that chronic pain will disappear over time (Amtmann et al. 2015; Finan et al. 2013). However, despite its high incidence, pain is often inadequately treated or neglected symptom in MS (Wright 2012).

\section{Fatigue and sleep}

The feeling of fatigue is one of the most frequently reported symptoms by patients with MS. Fatigue usually causes a set of symptoms, both physical and mental, causing, among others, reduced activity of the patient, faster fatigue, difficulties in thinking, apathy, quick forgetting and feeling of lack of energy. The scale of the problem is extremely large; depending on the sources, up to $53 \%$ to $92 \%$ of patients with MS complain about general fatigue and excessive daytime sleepiness (EDS). As many as $28-60 \%$ of patients consider fatigue to be the most annoying symptom in MS (Maestri et al. 2019). Fatigue is also the main cause of deterioration of the quality of life in patients with MS (Janardhan and Bakshi 2002). The pathomechanisms causing this condition are not fully known. The most frequently proposed explanation indicates a mechanism related to the inflammatory process, which results in excessive production of proinflammatory cytokines, dysfunction of the hormonal regulation of the hypothalamic-pituitary-adrenal axis, secondary damage to axons and lack of proper nervous system excitability. Inflammatory mediators, such as interferon- $\gamma$ and TNF- $\alpha$, are reported to have higher expression in MS patients, especially those suffering from fatigue. Fatigue in multiple sclerosis may also result from the accumulation of various disabilities and accompanying symptoms, including depression and sleep disorders (Braley and Chervin 2010; Heesen et al. 2006; Najafi et al. 2013). Many studies have shown that sleep-related breathing disorders are associated with excessive daytime sleepiness and fatigue in patients with MS. In a study by Kaynak et al. (2006), fatigued patients with MS were more likely to experience poorer sleep quality compared to non-fatigued patients with MS using the PQSI questionnaire.

\section{Sleep disorders and cognitive functions}

Cognitive dysfunction is one of the most common symptoms of MS. Interestingly, a decrease in cognitive capacity is found in all types of MS, including the clinically isolated syndrome (CIS) and radiologically isolated syndrome (RIS). Depending on the study, its prevalence in the MS population ranges from $34 \%$ to $65 \%$ (Kalb et al. 2018). Despite the high prevalence of cognitive disorders, other symptoms of MS, such as motor and sphincter disorders, often come to the fore and the patient and doctor's attention is focused on them. Also, many doctors do not pay enough attention to the problems of patients related to their progressive dysfunction of memory and executive functions. Often these symptoms lead to losing a job, which significantly affects the quality of life of patients (Braley et al. 2016; Benedict et al. 2005). Cognitive impairment is obviously due to progressive brain damage, but may be particularly associated with other symptoms of MS. The increased prevalence of OSA in patients with MS was mentioned above. So far, there have been many reports of a relationship between cognitive impairment and obstructive sleep apnoea (Braley and Chervin 2015). Braley et al. (2016) showed that in patients with MS, co-occurring OSA correlates with a decrease in 
cognitive functions. They put forward the thesis that hypoxia associated with obstructive sleep apnoea may concern brain areas associated with cognitive functions. For several years there have been discussions on the need for regular screening tests to examine cognitive impairment in patients with MS by doctors during follow-up visits. As a minimum, the 2014 recommendations recommend that the Symbol Digit Modalities Test (SDMT) be performed at the onset of the disease and that they be assessed annually or more frequently (in case of treatment changes or significant progress of the disease) using the same tool (Kalb et al. 2018). In addition to the SDMT, a large range of test tools such as the Paced Auditory Serial Addition Test (PASAT), the California Verbal Learning Test-II (CVLT-II) could be also chosen, but these require more time to perform and additional participation of a neuropsychologist (Kalb et al. 2018). According to the above-mentioned recommendations, the knowledge about whether the patient's cognitive functions are being progressively impaired may allow the intervention allowing adjusting the conditions at work, home or school and thus facilitating the patient's everyday functioning (Kalb et al. 2018).

\section{Correlation of radiological changes and sleep disorders in patients with MS}

There is currently no evidence that focal damage to the central nervous system (CNS) found in magnetic resonance imaging (MRI) is related to primary insomnia. However, individual sleep disorders, such as RLS, SDB or nycturia, are related to the corresponding distribution of demyelinating changes in the central nervous system. Sleep disorders caused by nycturia associated with the neurogenic bladder correlate with the presence of changes within the pons where the micturition centre is located (Barrington's nucleus) and within the sacral segment of the spinal cord (Foschi et al. 2019). Demyelinating changes in the brain stem are found more often in patients with $\mathrm{SDB}$. The pathophysiology of this phenomenon may be explained by localization of the respiratory centres in medulla oblongata - nucleus ambiguus and the solitary nucleus (Braley et al. 2012).

Bruno et al. (2015) compared MRI of patients with MS, who were also diagnosed with RLS, with patients with MS who did not suffer from RLS. It was shown that patients with MS/RLS+ had more demyelinating changes in the cervical section of the spinal cord than patients with MS/RLS-.

\section{Treatment of sleep disorders}

A key step in the extremely difficult treatment of sleep disorders seems to be the appropriate action on individual factors affecting sleep. In patients with sudden urinary urgency, cholinolytic drug or $\beta_{3}$-adrenergic receptor agonists may be considered before bedtime or, in case of persistent symptoms, refer the patient to surgery. If the cause is chronic pain, the treatment with drugs that are effective against neuropathic pain should be adjusted accordingly (Colloca et al. 2017). In the case of high spasticity, muscle relaxants such as baclofen or tizanidine may be essential for the treatment of sleep disorders, which also have a sedative and sleeping effect. The pharmacological treatment of depression, which itself predisposes to sleep disorders, is also crucial.

Non-pharmacological methods of treating insomnia are extremely important, i.e. observing the rules of proper sleep hygiene and behavioural and psychological techniques. By proper sleep hygiene we mean, among other things, following a healthy diet, avoiding the use of stimulants, maintaining a constant daily schedule, avoiding taking naps during the day, avoiding exposure to sharp light before bedtime and limiting staying in bed only for sleeping. Behavioural and psychological techniques also play an important role in the treatment of sleep disorders, which aim to identify inappropriate sleeping behaviour, improve the approach to sleep disorders and regulate the sleep pattern. Among other things, cognitive behavioural therapy and relaxation training are used (Gałecki and Szulc 2018).

Sadeghi Bahmani et al. (2019) from Switzerland conducted a study to check whether regular exercise has a positive effect on sleep, mood and cognitive function in patients with MS. Patients performed a 60-minute physical effort every day for 3 weeks. The results showed that the 3-week exercise program brought about an improvement in both sleep and cognitive function.

In the case of exhaustion of various therapies for high sleep deprivation, short-term use of nonbenzodiazepine GABA receptor agonists or benzodiazepines should also be considered (Braley and Chervin 2015).

Table 4 shows the drugs most commonly used in sleep disorders (Braley and Chervin 2015; Gałecki and Szulc 2018; Szczeklik and Gajewski 2019; Colloca et al. 2017; Corcos 2017; Wichniak et al. 2017).

\section{Summary}

MS, like any chronic disease causing, among other things, motor disability, pain and mood disorders, affects the quality and length of sleep. On the one hand, studies conducted so far show that sleep disorders in MS are rather secondary in nature and are more frequently observed in more advanced stages of the disease. On the other hand, sleep disorders are a practical problem, often not diagnosed and not treated sufficiently, having a large impact on the patient's functioning and quality of life. In addition, the occurrence of such abnormalities as 
Table 4. Treatment used for sleep disorders and in case of symptoms that exacerbate sleep disorders

\begin{tabular}{|c|c|}
\hline Disorder & Method of therapy \\
\hline RLS & $\begin{array}{l}\text { - reduction or withdrawal of drugs and stimulants that may exacerbate RLS (dopamine antagonists, lithium } \\
\text { compounds, SSRIs, SNRIs, antihistamines, TCAs, alcohol, nicotine, caffeine) } \\
\text { - use of dopamine agonists (pramipexole, ropinirol, rotigotine) or, where their use is not recommended, } \\
\text { the inclusion of pregabalin, gabapentin or carbamazepine } \\
\text { - iron supplementation in case of anaemia }\end{array}$ \\
\hline Obstructive sleep apnoea & $\begin{array}{l}\text { - change of the lifestyle, } \\
\text { - CPAP, BIPAP, oral devices bringing the jaw forward, } \\
\text { - surgical treatment (septoplasty, tonsillectomy, uvulopalatopharyngoplasty, osteotomy of the hyoid } \\
\text { bone) } \\
\text { - implantation of a hypoglossal nerve stimulator }\end{array}$ \\
\hline Insomnia & $\begin{array}{l}\text { - proper sleep hygiene } \\
\text { - behavioural and psychological techniques } \\
\text { - non-benzodiazepine GABA-receptor agonists (zolpidem, zopiclone, zaleplon) } \\
\text { - antidepressants (mianserin, mirtazapine, trazodone) } \\
\text { - antipsychotics (quetiapine, olanzapine, chlorprothixene) } \\
\text { - in unique cases, benzodiazepines (temazepam, estazolam) or hydroxyzine }\end{array}$ \\
\hline Increased muscle tension & - Muscle relaxants (baclofen, tizanidine) \\
\hline Depression & $\begin{array}{l}\text { - SSRI (fluoxetine, fluvoxamine, citalopram, escitalopram, sertraline, paroxetine) } \\
\text { - SNRI (venlafaxine, duloxetine) } \\
\text { - other drugs (bupropion, mianserin, mirtazapine, reboxetine, trazodone, tianeptine, agomelatine, } \\
\text { moclobemide) }\end{array}$ \\
\hline Neuropathic pain & $\begin{array}{l}\text { - gabapentin, pregabalin } \\
\text { - SNRI (duloxetine, venlafaxine) } \\
\text { - TCAs (nortriptyline, desipramine, amitriptyline, clomipramine and imipramine) } \\
\text { - less commonly used: } 5 \% \text { lidocaine patches, opioids (tramadol, morphine, oxycodone), botulinum toxin }\end{array}$ \\
\hline $\begin{array}{l}\text { Circadian rhythm sleep-wake } \\
\text { disorders }\end{array}$ & $\begin{array}{l}\text { - melatonin } \\
\text { - phototherapy } \\
\text { - avoiding exposure to light at times of day designated by the doctor }\end{array}$ \\
\hline Overactive bladder syndrome & $\begin{array}{l}\text { behavioural therapy (bladder and pelvic floor muscle training), lifestyle change (stimulant reduction, diet) } \\
M_{3} \text { receptor antagonists (solifenacin) } \\
\text { anticholinergics (oxybutynin) } \\
\text { selective } \beta_{3} \text { adrenergic receptor agonist (mirabegron) }\end{array}$ \\
\hline
\end{tabular}

SSRI - selective serotonin reuptake inhibitors; SNRI - Serotonin-norepinephrine reuptake inhibitor; TCA - tricyclic antidepressants; CPAP continuous positive airway pressure; BIPAP - biphasic positive airway pressure

obstructive sleep apnoea or restless legs syndrome, which tend to be more common in patients with MS than in the general population, is rarely noted. Poor quality of sleep or insufficient duration of sleep may significantly disturb the daily functioning of patients, lead to sleepiness during the day, reduced productivity at work, impaired concentration, attention, memory, increased anxiety and depression. Therefore, it is extremely important that patients are properly assessed for sleep disorders and that they are properly diagnosed. Patients should be advised to eliminate the factors causing sleep disorders, which they can control themselves. These include taking naps during the day, changing hours of sleep, lack of physical activity during the day or excessive exercise just before bedtime, taking stimulants and eating hard to digest food before going to bed. Adhering to proper sleep hygiene and appropriate therapy can improve the quality of sleep and also affect a number of accompanying disorders, thus improving the functioning of patients with MS.

\section{Wstęp}

Stwardnienie rozsiane (sclerosis multiplex, SM) to przewlekła zapalna choroba układu nerwowego, która charakteryzuje się występowaniem deficytów neurologicznych wycofujących się lub postępujących w czasie. Liczbę chorych na SM szacuje się na około 2,5 miliona ludzi na całym świecie (Najafi i wsp. 2013). Najwyższy wskaźnik rozpowszechnienia SM występuje w Ameryce Północnej oraz Europie. Choroba ta ujawnia się najczęściej w wieku 20-40 lat i dotyczy dwukrotnie częściej kobiet niż mężczyzn. Stanowi jedną z najważniejszych przyczyn niepełnosprawności u młodych osób, głównie z powodu postępującej niesprawności ruchowej, ale również deficytów 
poznawczych, zaburzeń widzenia, zaburzeń równowagi oraz wielu innych objawów dotychczas w mniejszym stopniu wiązanych ze stwardnieniem rozsianym (Bishop i Rumrill 2015; Sakkas i wsp. 2019; Veauthier 2015).

Jednym z zaburzeń towarzyszących SM są zaburzenia snu. Sugeruje się, że zaburzenia snu występują w populacji chorych na SM częściej niż w populacji ogólnej (Morse i Kothare 2018; Sakkas i wsp. 2019; Veauthier 2015). Według dotychczas przeprowadzonych badań problemy związane ze snem dotyczyć mogą nawet od 42 do 46 procent pacjentów. Oznacza to, że mogą występować one w tej grupie chorych nawet cztery razy częściej niż w populacji ogólnej (Sakkas i wsp. 2019). Częstość występowania zaburzeń snu u chorych na SM wykazuje zmienność w zależności od czasu trwania choroby. W badaniu przeprowadzonym przez Vitkova i wsp. (2014) porównano zaburzenia snu u chorych na SM, podzieliwszy chorych na dwie grupy w zależności od czasu trwania choroby (do 5 lat i powyżej 5 lat). Wykazano, iż zaburzenia snu występują częściej u chorych z dłuższym czasem trwania choroby (34,8\% vs 51,2\%), co korelowało także z wyższym wynikiem EDSS (Vitkova i wsp. 2014). Wskazywać by to mogło na ich wtórny charakter, zależący od dodatkowych deficytów pojawiających się w czasie trwania choroby. Na jakość snu mogą wpływać dolegliwości takie jak nasilone odczucie zmęczenia, obniżony nastrój, zaburzenia funkcji poznawczych, przewlekły ból, zaburzenia funkcji seksualnych oraz zwieraczowych (Bishop i Rumrill 2015; Braley i Boudreau 2016; Sakkas i wsp. 2019). Objawy takie jak pęcherz neurogenny, przewlekły ból, spastyczność czy zaburzenia lękowe, często towarzyszące SM, mogą w znaczącym stopniu powodować trudności w inicjacji czy utrzymaniu snu (Braley i Chervin 2015).

\section{Podział zaburzeń snu}

Zaburzenia snu mogą przyjmować różne postacie (Morse i Kothare 2018). Dokładny ich podział definiuje Międzynarodowa Klasyfikacja Zaburzeń Snu (International Classification of Sleep Disorders, ICSD-3) (American Academy of Sleep Medicine 2014; Sateia 2014). Podział ten przedstawiono w tabeli 1.

\section{Bezsenność}

Według ICSD-3 bezsenność objawiać się może problemami z inicjacją snu, trudnościami z jego utrzymaniem lub przedwczesnym budzeniem się (Najafi i wsp. 2013; Thorpy 2012). Jest ona najczęstszą manifestacją zaburzeń snu i stanowi około 90\% wszystkich zaburzeń snu. Amerykańska Akademia Medycyny Snu (American Academy of Sleep Medicine, AASM) dokonała podziału bezsenności ze względu na czas jej trwania. Bezsenność krótkotrwała to bezsenność trwająca poniżej 3 miesięcy, a bezsenność przewlekła trwa ponad 3 miesiące.
Tabela 1. Międzynarodowa Klasyfikacja Zaburzeń Snu (ICSD-3) z 2014 roku. W tabeli zawarto najczęściej występujące zaburzenia

\begin{tabular}{|c|c|}
\hline I. Bezsenność & $\begin{array}{l}\text { Bezsenność przewlekła } \\
\text { Bezsenność krótkotrwała } \\
\text { Inne rodzaje bezsenności }\end{array}$ \\
\hline $\begin{array}{l}\text { II. Zaburzenia } \\
\text { oddychania } \\
\text { w czasie snu }\end{array}$ & $\begin{array}{l}\text { - Obturacyjny bezdech senny } \\
\text { - Ośrodkowy bezdech senny } \\
\text { - Zaburzenia hipowentylacji związane ze snem } \\
\text { - Hipoksemia związana ze snem }\end{array}$ \\
\hline $\begin{array}{l}\text { III. Zaburzenia } \\
\text { z hipersomnią } \\
\text { pochodzenia } \\
\text { ośrodkowego }\end{array}$ & $\begin{array}{l}\text { - Narkolepsja typ } 1 \\
\text { - Narkolepsja typ } 2 \\
\text { - Idiopatyczna hipersomnia } \\
\text { - Zespół Kleinego-Levina }\end{array}$ \\
\hline $\begin{array}{l}\text { IV. Zaburzenia } \\
\text { rytmu } \\
\text { okołodobowego }\end{array}$ & $\begin{array}{l}\text { - Zaburzenie z opóźnioną fazą snu } \\
\text { i czuwania } \\
\text { - Zaburzenie z przyspieszoną fazą snu } \\
\text { i czuwania } \\
\text { - Zaburzenie z nieregularnym rytmem snu } \\
\text { i czuwania } \\
\text { - Zaburzenie z innym niż 24-godzinnym } \\
\text { rytmem snu i czuwania } \\
\text { - Zaburzenie związane z pracą zmianową } \\
\text { - Zaburzenie jet lag } \\
\text { - Zaburzenia rytmu sen-czuwanie szerzej } \\
\text { nieokreślone }\end{array}$ \\
\hline V. Parasomnie & $\begin{array}{l}\text { - Parasomnie snu NREM } \\
\text { - Parasomnie snu REM } \\
\text { - Inne parasomnie }\end{array}$ \\
\hline $\begin{array}{l}\text { VI. Zaburzenia } \\
\text { ruchowe związane } \\
\text { ze snem }\end{array}$ & $\begin{array}{l}\text { - Zespół niespokojnych nóg } \\
\text { - Zespół okresowych ruchów kończyn } \\
\text { - Bruksizm } \\
\text { - Zaburzenia z rytmicznymi ruchami } \\
\text { w czasie snu } \\
\text { - Zaburzenia ruchowe związane ze snem } \\
\text { (nieokreślone, związane z chorobami } \\
\text { somatycznymi, stosowaniem leków lub } \\
\text { innych substancji) }\end{array}$ \\
\hline
\end{tabular}

Według najnowszej wersji ICD-11 (International Classification of Diseases, wersja 11) bezsenność charakteryzuje się utrzymującymi się trudnościami z zapoczątkowaniem snu, jego nieprawidłowym czasem trwania, konsolidacją lub jakością, a trudności te występują pomimo odpowiednich możliwości i warunków do spania i skutkują upośledzeniem funkcjonowania w ciągu dnia. Objawy występujące w ciągu dnia zwykle obejmują zmęczenie, obniżony nastrój lub drażliwość, ogólne złe samopoczucie i zaburzenia poznawcze. Osoby, które zgłaszają objawy związane ze snem przy braku upośledzenia funkcjonowania w ciągu dnia, nie są uważane za osoby cierpiące na bezsenność (World Health Organization 2018).

W tabeli 2 przedstawiono natomiast kryteria rozpoznania bezsenności wg DSM-V (American Psychiatric Association 2013).

Znane czynniki ryzyka wystąpienia bezsenności to starszy wiek, płeć żeńska, niższe wykształcenie, współistniejące zaburzenia somatyczne i psychiczne (Wojtas i Ciszewski 2011). 
Tabela 2. Kryteria diagnostyczne bezsenności wg DSM-V

Kryteria diagnostyczne:
A. Skargi na niezadowalającą ilość lub jakość snu, związane
z jednym (lub więcej) następujących objawów:
1. trudności w inicjacji snu (u dzieci może się to objawiać
trudnościami w zainicjowaniu snu bez interwencji opiekuna);
2. trudności w utrzymaniu snu, charakteryzujące się częstymi
$\quad$ przebudzeniami lub problemami z powrotem do snu po
$\quad$ przebudzeniu (u dzieci może się to objawiać trudnościami
$\quad$ z powrotem do snu bez interwencji opiekuna)
3. Wczesne budzenie się z niemożnością powrotu do snu.
B. Zaburzenia snu powodują klinicznie istotny niepokój lub
dysfunkcję w sferze społecznej, zawodowej, edukacyjnej,
akademickiej, behawioralnej lub w innych ważnych obszarach
funkcjonowania.
C. Trudności w zasypianiu występują przynajmniej 3 razy
w tygodniu.
D. Trudności w zasypianiu są obecne od co najmniej 3 miesięcy.
E. Trudności w zasypianiu występują pomimo odpowiednich
możliwości snu.
F. Bezsenność nie może być wyjaśniona i nie występuje wyłącznie
w przebiegu innego zaburzenia snu-budzenia (np. narkolepsja,
zaburzenia oddychania związane ze snem, zaburzenia rytmu
okołodobowego snu-budzenia, parasomnia).
G. Bezsenność nie wynika ze skutków działania substancji
(np. nadużywania narkotyków, leków).
H. Współistniejące zaburzenia psychiczne i stan zdrowia nie
wyjaśniają w wystarczający sposób dominującej skargi na
bezsenność.

Nie wykonano dotychczas na większą skalę badań epidemiologicznych oceniających częstość występowania bezsenności u chorych na SM. W mniejszych badaniach szacuje się, że występuje u 40-50\% chorych (Sakkas i wsp. 2019). W badaniu Bøe i wsp. (2012), w którym przebadano 90 chorych na SM, zaburzenia snu - na podstawie Kwestionariusza Jakości Snu Pittsburgh (Pittsburgh Sleep Quality Index, PSQI) - stwierdzono u 67,1\% badanych. Okazało się, że zaburzenia snu u tych chorych związane były z objawami bólowymi, depresją i zmęczeniem i częściej występowały u kobiet oraz u chorych stosujących immunoterapię. Wykazano także, że najczęstszym przejawem bezsenności u chorych na SM jest trudność $\mathrm{z}$ inicjacją snu (Bøe i wsp. 2012).

Stanton i wsp. (2006) przebadali pacjentów z SM pod kątem bezsenności oraz przyczyn jej występowania. Do najczęstszych czynników powodujących bezsenność należały lęk, ból oraz obniżony nastrój. W badaniu stwierdzono trudności z inicjacją snu u $42 \%$ z 60 przebadanych pacjentów.

\section{Zaburzenia rytmu okołodobowego}

Rytm okołodobowy (circadian activity rhythm, CAR) jest jednym z najważniejszych mechanizmów, który ma wpływ na czas trwania oraz jakość snu człowieka. Rytm okołodobowy to cykl zmian procesów fizjologicznych, takich jak ruch, spoczynek, sen, odżywanie się w czasie doby, które regulowane są przez zegar biologiczny. Centralny zegar biologiczny znajduje się w podwzgórzowej części ośrodkowego układu nerwowego w jądrach nadskrzyżowaniowych. Praca zegara biologicznego polega na rytmicznym włączaniu i wyłączaniu transkrypcji tak zwanych genów zegarowych. Rytm okołodobowy jest regulowany w dużej mierze przez melatoninę wydzielaną przez szyszynkę. Oddziałuje ona na receptory $\mathrm{MT}_{1} \mathrm{i} \mathrm{MT}_{2}$, które znajdują się w wielu obszarach mózgu, między innymi w jądrze nadskrzyżowaniowym, hipokampie, ciele migdałowatym, móżdżku oraz w innych komórkach organizmu, takich jak komórki siatkówki i trzustki (Skarlis i Anagnostouli 2019).

Obecnie zaburzenia CAR coraz częściej odnotowywane są w populacji ogólnej. Wynika to w dużej mierze ze stylu życia, w tym pracy zmianowej, wielogodzinnej aktywności umysłowej, małej ilości sportu, nieregularnego odżywania się oraz małej ilości czasu spędzanego na powietrzu i tym samym niskiej ekspozycji na światło słoneczne. Udowodniono, że pewne choroby mogą prowadzić do częstszego występowania zaburzeń rytmu okołodobowego. Takim schorzeniem jest choroba Alzheimera, w której występuje zmniejszenie liczby neuronów jądra nadskrzyżowaniowego, co prowadzi do utraty jego funkcji regulowania rytmu okołodobowego (Wichniak i wsp. 2017).

Zagadnienie zaburzeń rytmu okołodobowego u pacjentów chorych na SM nie jest jeszcze dobrze zbadane, jednakże zainteresowanie badaczy tym tematem wzrasta. Wykryto, iż geny regulatorowe związane z rytmem okołodobowym, takie jak ARNTL i CLOCK, mogą mieć związek z częstością występowania SM. Geny te wykazują dużą zmienność, a występowanie niektórych genotypów może stanowić czynnik zwiększonego ryzyka wystąpienia SM. W dotychczas przeprowadzonych badaniach nad częstością występowania CAR u pacjentów z SM uzyskano sprzeczne wyniki (Tonetti i wsp. 2019). W badaniu Taphoorn i wsp. (1993) nie wykazano zaburzeń CAR u pacjentów z SM, z kolei w badaniu Najafi i wsp. (2013) potwierdzono związek częstszego występowania zaburzeń CAR u chorych z SM. W ostatnim czasie w Bolonii Tonetti i wsp. (2019) przebadali 35 chorych na SM. Do kryteriów włączenia należały: wiek 18-65 lat, poniżej 2 lat od rozpoznania SM, prowadzona terapia modulująca przebieg choroby powyżej 6 miesięcy, brak rzutów oraz sterydoterapii w ciągu ostatniego miesiąca, brak pracy w nocnym trybie zmianowym, brak wspólistniejących chorób przewlekłych oraz psychiatrycznych, brak stwierdzonych zaburzeń snu, zaburzeń motorycznych, niestosowanie substancji psychoaktywnych. Badanie przeprowadzono za pomocą aktygrafu, miernika ruchu służącego do ciągłej rejestracji aktywności całodobowej. Wyniki badania wskazały, że czas trwania snu pacjentów chorych na SM w porównaniu z grupą kontrolną, którą stanowiły osoby zdrowe, był taki sam, jednak sen był nieznacznie gorszej 
jakości. Podsumowując te wyniki, badacze uznali, że wpływ choroby na CAR na wczesnym jej etapie może być znacznie mniejszy niż wtedy, kiedy choroba jest w bardziej zaawansowanym stadium, kiedy pacjenci cierpią częściej na inne czynniki predysponujące do zaburzeń snu, np. dysfunkcję zwieracza pęcherza moczowego czy zespół niespokojnych nóg (Tonetti i wsp. 2019).

W kontekście CAR warto wspomnieć, że naukowcy od lat 90. badają związek melatoniny z patogenezą i przebiegiem SM. W większości przeprowadzonych na ten temat badań stwierdzono obniżone stężenie melatoniny w surowicy lub jej metabolitów w moczu u pacjentów z SM. Może to wskazywać na ewentualne znaczenie jej niedoboru w patogenezie SM. Korelacja pomiędzy przebiegiem choroby a stężeniem melatoniny we krwi pozostaje jak dotąd nieznana, a dotychczas przeprowadzone badania przynoszą sprzeczne dane na ten temat (Skarlis i Anagnostouli 2019). Damasceno i wsp. (2015) uzyskali wyniki potwierdzające związek pomiędzy obniżoną ilością metabolitów melatoniny w moczu a nasileniem zmęczenia, liczbą rzutów choroby i wyższą punktacją w Rozszerzonej Skali Niepełnosprawności (Expanded Disability Status Scale, EDSS) u osób chorych na SM. Tymczasem badania Farhadi i wsp. (2014) i Gholipour i wsp. (2015) nie potwierdziły zależności pomiędzy obniżonym stężeniem melatoniny w surowicy a wyższym wynikiem EDSS. Obecnie prowadzone są badania na temat roli melatoniny w terapii SM. Badania te mają na celu ocenić, czy stosowanie melatoniny może mieć ewentualny wpływ na przebieg choroby, a także na zaburzenia snu lub depresję (Skarlis i Anagnostouli 2019).

\section{Zespół niespokojnych nóg}

Jedną z częstych i niezwykle dotkliwych dolegliwości związanych ze snem jest zespół niespokojnych nóg (restless legs syndrome, RLS). Zespół ten polega na występowaniu poczucia silnego przymusu poruszania kończynami dolnymi. Objawy występują najczęściej wieczorem lub w nocy. Ulgę przynosi ruch kończyn. Wyróżnia się dwie postacie RLS - idiopatyczną oraz wtórną. Postać idiopatyczna występuje częściej, prawdopodobnie może być ona dziedziczna, ponieważ większość pacjentów zgłasza rodzinne występowanie tego zaburzenia. Charakteryzuje się także częstszym występowaniem u kobiet i jej częstość rośnie z wiekiem. Postać wtórna ma związek z niedoborem żelaza, ciążą oraz niewydolnością nerek. Udowodniono także związek częstszego występowania RLS u pacjentów z miastenią, celiakią, chorobami wątroby, reumatoidalnym zapaleniem stawów, pierwotnymi bólami głowy lub neuropatiami (Allen i wsp. 2013; Lee i wsp. 2013; Manconi i wsp. 2004; Siemiński i wsp. 2015). W populacji ogólnej częstość występowania RLS wynosi około 5\% (Gałecki i Szulc 2018).

U chorych z SM stwierdzono zwiększoną częstość występowania RLS. W zależności od różnych badań częstość wynosiła od 13,3\% nawet do 65,1\%. Rozbieżności wynikały prawdopodobnie z kilku aspektów. Między innymi podobieństwa objawów RLS i SM - pacjenci w obu tych schorzeniach zgłaszają często podobne objawy czuciowe: parestezje, takie jak drętwienie czy pieczenie, które, o ile nie wykazują zmienności w zależności od pory dnia, nie mogą być uznane za kryterium rozpoznania RLS. Siemiński i wsp. (2015) dokonali analizy trzynastu dotychczas przeprowadzonych badań korelacji RLS i SM. U pacjentów chorych na stwardnienie rozsiane nie potwierdzono silnego związku płci żeńskiej, rodzinnego występowania oraz starszego wieku z częstszym występowaniem RLS. W zaledwie dwóch analizowanych badaniach u chorych z SM potwierdzono częstsze występowanie RLS u kobiet, a pacjenci z RLS byli starsi od pacjentów bez RLS. Rodzinny związek RLS u pacjentów z SM potwierdzono u 2,4\% do 27,1\% pacjentów w zależności od badania. Jest to znacznie mniejszy odsetek niż w postaci idiopatycznej RLS (Siemiński i wsp. 2015). W części badań udowodniono także, że pacjenci ze stwierdzonym RLS mają wyższą punktację w EDSS (Manconi i wsp. 2007; Sieminski i wsp. 2015). W części opracowań wysunięto podejrzenie, że postać pierwotnie postępująca może wiązać się z częstszym występowaniem RLS niż w pozostałych postaciach SM (Sakkas i wsp. 2019).

Connor i wsp. (2011) dokonali analizy pośmiertnej mieliny pochodzącej z mózgu pacjentów z RLS oraz analizę objętości istoty szarej i białej mózgu za pomocą morfometrii opartej na wokselach w badaniu MRI mózgów pacjentów z RLS. Badanie wykazało, że pacjenci z RLS mają zmniejszoną ilość mieliny, a także obniżoną ilość ferrytyny i transferryny we frakcji mieliny, co wskazuje na obniżoną ilość żelaza w mózgu chorych na RLS. Sugeruje to, że uszkodzenie mieliny może być związane z etiopatogenezą RLS i w ten sposób SM może być chorobą predysponującą do rozwoju tego zaburzenia.

\section{Zaburzenia oddychania w czasie snu}

Najczęstszą postacią zaburzeń oddychania w czasie w snu (sleep disordered breathing, SDB) jest obturacyjny bezdech senny (obstructive sleep apnea, OSA). OSA to schorzenie polegające na wielokrotnym występowaniu w czasie snu epizodów bezdechu lub znacznego spłycenia oddychania (Kuzminska 2011). W populacji ogólnej częstość występowania OSA szacuje się w zależności od źródła na $2 \%$ u kobiet i $4 \%$ u mężczyzn (Young i wsp. 1993) do nawet 5,7\% u kobiet i 12,4\% u mężczyzn (Simpson i wsp. 2013). Znanymi czynnikami ryzyka wystąpienia OSA są nadciśnienie tętnicze, cukrzyca, zespół metaboliczny i depresja (Simpson i wsp. 2013). Złotym standardem diagnozowania w kierunku OSA jest badanie polisomnograficzne. Do kryteriów rozpoznania OSA za pomocą polisomnografii należy, według AASM, stwierdzenie minimum 15 epizodów oddechowych (wskaźnik RDI) pod postacią: bezdechów, spłycenia oddechu, 
przebudzeń związanych z wysiłkiem oddechowym, niezależnie od obecności objawów klinicznych (RDI 215) lub RDI >5 w przypadku osób z przynajmniej jednym spośród takich objawów, jak: 1) zasypianie wbrew własnej woli, nadmierna senność dzienna, zmęczenie, bezsenność, nieefektywny sen; 2) przebudzenia z uczuciem zatrzymania oddechu, duszność lub dławienie; 3) głośne chrapanie lub bezdechy stwierdzane przez osobę sypiającą z chorym (Szczeklik i Gajewski 2019). Z uwagi na to, że badanie polisomnograficzne jest dosyć trudne do przeprowadzenia pod względem logistycznym oraz dosyć kosztowne w przypadku większej liczby pacjentów, stosuje się również kwestionariusze, takie jak kwestionariusz berliński oraz kwestionariusz STOP-Bang, które informują o ryzyku OSA (Simpson i wsp. 2013).

Częstość występowania OSA u chorych na SM - w zależności od źródeł - może sięgać nawet do $58 \%$. W tabeli 3 przedstawiono podsumowanie badań dotyczących OSA u chorych na SM. W badaniu przeprowadzonym przez Braley i wsp. (2014) dokonano oceny ryzyka OSA u pacjentów z SM, z których $21 \%$ miało już wcześniej rozpoznanie OSA. U 56\% wszystkich badanych stwierdzono podwyższone ryzyko wystąpienia OSA - na podstawie wyniku kwestionariusza STOP-Bang. U pacjentów z diagnozą OSA ryzyko, ocenione na podstawie tego kwestionariusza wyniosło $93 \%$.

Wiele wskazuje także na to, że zmęczenie w populacji chorych na SM może być silnie związane z nierozpoznanym i nieleczonym OSA (Braley i wsp. 2014; Kaminska i wsp. 2011). Złotym standardem leczenia OSA jest stosowanie urządzeń CPAP (Continuous Positive Airway Pressure - stałe dodatnie ciśnienie w drogach oddechowych). W jednym z badań wykazano istotne zmniejszenie uczucia zmęczenia i senności w trakcie dnia oraz poprawę jakości snu u pacjentów chorych na SM stosujących w ramach tego badania CPAP (Cote i wsp. 2013; Kaminska i wsp. 2014).

Do grupy SDB należy także centralny bezdech senny (central sleep apnea, CSA). Zaburzenia oddychania w tym schorzeniu wynikają z utrudnionego lub przerwanego przewodnictwa nerwowego lub uszkodzeń płytki nerwowo-mięśniowej, która unerwia mięśnie oddechowe. CSA związany może być z chorobami naczyniowymi, nowotworowymi, zwyrodnieniowymi, pourazowymi, a także demielinizacyjnymi pnia mózgu (Plywaczewski i wsp. 2013). Pacjenci z SM są narażeni na ryzyko wystąpienia centralnego bezdechu sennego z uwagi na obecność zmian demielinizacyjnych w obrębie pnia mózgu, w którym znajduje się ośrodek oddechowy (Braley i Chervin 2015).

Tabela 3. Podsumowanie badań dotyczących OSA i CSA u chorych na SM

\begin{tabular}{|c|c|c|c|c|}
\hline Autor & $\begin{array}{l}\text { Liczba } \\
\text { chorych }\end{array}$ & DMT & Metoda & Wyniki \\
\hline Brass i wsp. (2014) & $n=2375$ & Brak danych & $\begin{array}{l}\text { Kwestionariusz } \\
\text { STOP-Bang } \\
\text { Kwestionariusz Berliński }\end{array}$ & $\begin{array}{l}n=898 \\
37,8 \% \text { podwyższone ryzyko OSA }\end{array}$ \\
\hline Braley i wsp. (2012) & $n=48$ & DMT u $69,75 \%$ & Polisomnografia & $\begin{array}{l}n=27 \text { OSA } 56 \% \\
n=2 \text { CSA } 4,17 \% \\
n=3 \text { CSA I OSA } 6,25 \%\end{array}$ \\
\hline Sater i wsp. (2015) & $n=32$ & $\begin{array}{l}\text { Nieleczeni, } \\
\text { Planowani do włączenia DMT } \\
\text { natalizumabem }\end{array}$ & Polisomnografia & $n=12$ OSA $37,5 \%$ badanych \\
\hline $\begin{array}{l}\text { Kaminska i wsp. } \\
\text { (2011) }\end{array}$ & $n=62$ & $\begin{array}{l}\text { DMT u } 69 \% n=43 \text { : octan } \\
\text { glatirameru } n=20 ; \\
\text { interferon beta-1a } n=7 ; \\
\text { interferon beta-1b } n=8 ; \\
\text { cyklofosfamid } n=3 ; \\
\text { mitoksantrone } n=2 ; \text { natalizumab } \\
n=2 ; \text { fingolimiod } n=1\end{array}$ & Polisomnografia & $n=36$ OSA, $58 \%$ badanych \\
\hline $\begin{array}{l}\text { Čarnická i wsp. } \\
\text { (2015) }\end{array}$ & $n=50$ & Brak danych & Polisomnografia & $\begin{array}{l}n=11 \text { OSA, } 22 \% \text { badanych } \\
n=3 \text { CSA, } 6 \% \text { badanych }\end{array}$ \\
\hline $\begin{array}{l}\text { Tachibana i wsp. } \\
\text { (1994) }\end{array}$ & $n=28$ & Brak danych & Polisomnografia & $n=2$ OSA, $7,14 \%$ badanych \\
\hline $\begin{array}{l}\text { Veauthier i wsp. } \\
\text { (2011) }\end{array}$ & $n=66$ & Brak danych & Polisomnografia & $\begin{array}{l}n=6 \text { OSA, } 9,09 \% \text { badanych } \\
n=1 \text { CSA, } 1,52 \% \text { badanych }\end{array}$ \\
\hline Braley i wsp. (2014) & $n=195$ & $\begin{array}{l}\text { DMT u 68,2\%: } \\
\text { beta-interferon 31,3\%; } \\
\text { octan glatirameru 23,6\%; } \\
\text { natalizumab 8,7\%; } \\
\text { inne leki 4,1\% }\end{array}$ & $\begin{array}{l}\text { Kwestionariusz } \\
\text { STOP-Bang }\end{array}$ & $\begin{array}{l}n=110,56 \% \text { wszystkich badanych } \\
\text { podwyższone ryzyko OSA } \\
n=41,21 \% \text { z wcześniejszą diagnozą } \\
\text { OSA, na podstawie STOP-Bang. } \\
93 \% \text { z tych pacjentów podwyższone } \\
\text { ryzyko OSA. }\end{array}$ \\
\hline
\end{tabular}

DMT - disease modifying therapy / terapia modyfikująca przebieg choroby 


\section{Czynniki wpływające na sen u pacjentów z SM}

\section{Zaburzenia nastroju}

Obniżony nastrój wynikający z samej obecności choroby, a także z jej postępu predysponuje do częstszego występowania depresji u pacjentów z SM. Szacuje się, że na depresję chorować może nawet $50 \%$ chorych (Braley i Chervin 2010). Jednym z podstawowych objawów depresji są zaburzenia snu, tym samym zaburzenia afektywne wymagają szczegółowej diagnostyki u pacjentów z zaburzeniami snu. Dodatkową trudność sprawia fakt, że upośledzony sen jest zarówno czynnikiem ryzyka, jak i objawem depresji. Udowodniono już w licznych badaniach, że pacjenci z depresją wykazują zmiany w EEG w czasie snu (Steiger i Pawlowski 2019). W badaniu Bøe i wsp. (2012) dotyczącym zaburzeń snu u chorych na SM wykazano, że spośród wszystkich badanych u pacjentów, u których rozpoznano depresję, jednocześnie stwierdzono zaburzenia snu. Związek ten prawdopodobnie jest dwukierunkowy - depresja nasila objawy zaburzeń snu, a sen nasila objawy depresji. Odpowiednio dobrane leczenie przeciwdepresyjne zmniejsza dolegliwości związane ze snem.

\section{Ból}

Ostry i przewlekły ból jest częstym objawem w SM i obejmuje zarówno ból neuropatyczny, jak i ból mięśniowo-szkieletowy, wtórny wobec innych objawów SM, takich jak np. spastyczność (Stenager i wsp. 1995). W badaniach populacyjnych oszacowano, że 55-65\% chorych na SM cierpi na zespoły bólowe o ostrym, podostrym lub przewlekłym charakterze (Bøe i wsp. 2012; O’Connor i wsp. 2008). Ból przewlekły, nie tylko u pacjentów z SM, jest czynnikiem związanym z jakością snu, głównie z zaburzeniem zasypiania. Wśród chorych z SM ból występował znacznie częściej u osób z zaburzeniami snu niż u osób śpiących dobrze (Bøe i wsp. 2012; Stanton i wsp. 2006). Niezależnie od płci i wieku pacjentów z SM odczuwanie bólu, złe radzenie sobie z bólem oraz depresja są czynnikami predysponującymi do występowania zaburzeń snu (Vega i wsp. 2019). Z jednej strony pacjenci z SM nie różnią się pod tym względem od chorych z innymi przewlekłymi zespołami bólowymi. Z drugiej strony kilka dużych prospektywnych badań sugeruje, że problemy ze snem zwiększają ryzyko rozwoju przewlekłego bólu w przyszłości, a dobry sen zwiększa szansę, że przewlekły ból z czasem ustąpi (Amtmann i wsp. 2015; Finan i wsp. 2013. Mimo częstego występowania ból jest jednak często nieodpowiednio leczonym lub pomijanym objawem w SM (Wright 2012).

\section{Zmęczenie i sen}

Uczucie zmęczenia jest jednym z najczęściej zgłaszanych objawów przez pacjentów z SM. Zmęczenie zwykle wywołuje zespół objawów zarówno fizycznych, jak i psychicznych, powodujących m.in. ograniczenie aktywności chorego, szybsze męczenie się, trudności w myśleniu, apatię, szybkie zapominanie i poczucie braku energii. Skala problemu jest niezwykle duża; w zależności od źródeł na uczucie ogólnego zmęczenia oraz nadmierną senność w ciągu dnia (excessive daytime sleepness, EDS) skarży się nawet od 53\% do 92\% chorych z SM. Aż 28-60\% pacjentów uważa zmęczenie za najbardziej dokuczliwy objaw w SM (Maestri i wsp. 2019). Zmęczenie jest też główną przyczyną obniżenia jakości życia u pacjentów z SM (Janardhan i Bakshi 2002). Nie do końca znane są patomechanizmy powodujące ten stan. Najczęściej proponowane wyjaśnienie wskazuje na mechanizm związany z procesem zapalnym, w wyniku którego dochodzi do nadmiernej produkcji cytokin prozapalnych, zaburzeń regulacji hormonalnej osi podwzgórze-przysadka-nadnercza oraz wtórnego uszkodzenia aksonów i braku prawidłowej pobudliwości układu nerwowego. Podaje się, że mediatory stanu zapalnego, takie jak interferon- $\gamma$ i TNF- $\alpha$, wykazują większą ekspresję u chorych na SM, zwłaszcza cierpiących na uczucie zmęczenia. Zmęczenie w stwardnieniu rozsianym może wynikać również z akumulacji różnych niepełnosprawności i objawów towarzyszących, w tym depresji i zaburzeń snu (Braley i Chervin 2010; Heesen i wsp. 2006; Najafi i wsp. 2013). W wielu badaniach udowodniono związek zaburzeń oddychania związanych ze snem z nadmierną sennością w ciągu dnia i zmęczeniem u chorych na SM. W badaniu Kaynak i wsp. (2006) u zmęczonych pacjentów z SM za pomocą kwestionariusza PQSI częściej stwierdzano gorszą jakość snu w porównaniu z pacjentami chorymi na SM nieodczuwającymi zmęczenia.

\section{Zaburzenia snu a funkcje poznawcze}

Dysfunkcja poznawcza to jeden z najczęstszych objawów SM. Co interesujące, obniżenie zdolności kognitywnych stwierdza się we wszystkich typach SM, w tym w klinicznie izolowanym zespole (clinically isolated syndrome, CIS) i radiologicznie izolowanym zespole (radiologically isolated syndrome, RIS). W zależności od badania częstość jego występowania w populacji SM waha się od 34\% do 65\% (Kalb i wsp. 2018). Mimo dużego rozpowszechnienia zaburzeń poznawczych często na pierwszy plan wysuwają się inne objawy SM, takie jak zaburzenia motoryczne i zwieraczowe, i to na nich skupia się bardziej uwaga pacjenta oraz lekarza. Także wielu lekarzy nie poświęca wystarczającej uwagi problemom pacjentów związanych z postępującymi u nich zaburzeniami pamięci oraz funkcji wykonawczych. Często objawy te prowadzą do utraty pracy, co w znaczący sposób przekłada się na jakość życia pacjentów (Braley i wsp. 2016; Benedict i wsp. 2005). Zaburzenia poznawcze w oczywisty sposób wynikają z postępujących uszkodzeń w mózgu, ale mogą wiązać się w szczególny sposób w innymi objawami SM. Powyżej 
wspomniano o zwiększonej częstości występowania OSA u pacjentów chorych na SM. Pojawiło się dotychczas dużo doniesień mówiących o związku pomiędzy obniżeniem funkcji poznawczych a obturacyjnym bezdechem sennym (Braley i Chervin 2015). Braley i wsp. (2016) pokazali, że u chorych na SM współtowarzyszący OSA koreluje z obniżeniem funkcji poznawczych. Wysunęli oni tezę, iż niedotlenienie związane z obturacyjnym bezdechem sennym dotyczyć może obszarów mózgu związanych z funkcjami poznawczymi. Od kilku lat trwają dyskusje nad potrzebą regularnego wykonywania przesiewowych testów badających zaburzenia funkcji poznawczych u pacjentów z SM przez lekarzy podczas wizyt kontrolnych. W rekomendacjach z 2014 r. jako minimum zaleca się wykonywanie na początku choroby testu dopasowania cyfr do symboli (Symbol Digit Modalities Test, SDMT) oraz coroczną lub częstszą (w przypadku zmiany leczenia lub znacznego postępu choroby) ich ocenę za pomocą tego samego narzędzia (Kalb i wsp. 2018). Poza SDMT wybrać można także spośród dużego wachlarza narzędzi w postaci testów, takich jak np. Paced Auditory Serial Addition Test (PASAT), California Verbal Learning Test-II (CVLT-II), jednak wymagają one większej ilości czasu, by je przeprowadzić, i dodatkowego udziału neuropsychologa (Kalb i wsp. 2018). Według wspomnianych rekomendacji uzyskanie wiedzy o tym, czy u pacjenta obserwuje się postępujące obniżenie funkcji poznawczych, pozwolić może na interwencję pozwalającą na dostosowanie warunków w pracy, domu czy szkole chorego i tym samym ułatwienie jego codziennego funkcjonowanie (Kalb i wsp. 2018).

\section{Korelacja zmian radiologicznych i zaburzeń snu u chorych z SM}

Obecnie nie ma dowodów na to, aby ogniskowe uszkodzenie ośrodkowego układu nerwowego (OUN) stwierdzane w badaniu rezonansem magnetycznym (magnetic resonanse imaging, MRI) miało związek z bezsennością pierwotną. Jednakże poszczególne zaburzenia snu, takie jak RLS, SDB lub nykturia, mają związek z odpowiadającym im rozmieszczeniem zmian demielinizacyjnych w ośrodkowym układzie nerwowym. Zaburzenia snu spowodowane nykturią związaną z pęcherzem neurogennym korelują z obecnością zmian w obrębie mostu, gdzie znajduje się ośrodek oddawania moczu (jądro Barringtona), oraz w obrębie krzyżowego segmentu rdzenia kręgowego (Foschi i wsp. 2019). U pacjentów z SDB stwierdza się częściej zmiany demielinizacyjne w pniu mózgu. Patofizjologię tego zjawiska można tłumaczyć zlokalizowaniem w rdzeniu przedłużonym ośrodków oddechowych - jądra dwuznacznego oraz jądra pasma samotnego (Braley i wsp. 2012).

Bruno i wsp. (2015) porównali MRI pacjentów z SM, u których zdiagnozowano także RLS, z pacjentami z SM niechorującymi na RLS. Wykazano, iż pacjenci SM/ RLS+ posiadali więcej zmian demielinizacyjnych w obrębie szyjnego odcinka rdzenia kręgowego niż pacjenci SM/RLS-.

\section{Leczenie zaburzeń snu}

Kluczowym krokiem w niezwykle trudnej terapii zaburzeń snu zdaje się być odpowiednie działanie na poszczególne czynniki wpływające na sen. U pacjentów z naglącymi parciami na pęcherz moczowy można rozważyć stosowanie leku cholinolitycznego lub agonistów receptorów $\beta_{3}$-adrenergicznych przed snem lub - w przypadku uporczywych objawów - skierować pacjenta do leczenia operacyjnego. Jeśli przyczyną jest przewlekły ból, należy odpowiednio dostosować terapię lekami działającymi skutecznie na ból neuropatyczny (Colloca i wsp. 2017). W przypadku dużej spastyczności podstawowe dla leczenia zaburzeń snu mogą być leki miorelaksujące, takie jak baklofen czy tyzanidyna, które wykazują również działanie uspokajające i nasenne. Kluczowe jest także farmakologiczne leczenie depresji, która sama predysponuje do wystąpienia zaburzeń snu.

Niezwykle ważne są niefarmakologiczne metody leczenia bezsenności, czyli przestrzeganie zasad odpowiedniej higieny snu oraz techniki behawioralne i psychologiczne. Przez odpowiednią higienę snu rozumiemy m.in. stosowanie zdrowej diety, unikanie stosowania używek, utrzymywanie stałego schematu dnia, unikanie drzemek w ciągu dnia, unikanie ekspozycji na ostre światło przed snem oraz ograniczenie przebywania w łóźku tylko do czasu spania. W leczeniu zaburzeń snu duże znaczenie odgrywają także techniki behawioralne i psychologiczne, które mają na celu zidentyfikowanie nieodpowiednich zachowań związanych ze snem, poprawę podejścia do zaburzeń snu, unormowanie schematu snu. Stosuje się między innymi terapię poznawczo-behawioralną oraz treningi relaksacyjne (Gałecki i Szulc 2018).

Sadeghi Bahmani i wsp. (2019) ze Szwajcarii przeprowadzili badanie mające na celu sprawdzenie, czy regularne ćwiczenia mają pozytywny wpływ na sen, nastrój i funkcje poznawcze u chorych na SM. Pacjenci przez 3 tygodnie wykonywali codziennie 60-minutowy wysiłek fizyczny. Wyniki wykazały, że 3-tygodniowy program ćwiczeń przyniósł poprawę zarówno snu, jak i funkcjonowania poznawczego.

W przypadku wyczerpania różnych metod terapii przy dużej deprywacji snu należy także rozważyć krótkotrwałe stosowanie leków z grupy niebenzodiazepinowych agonistów receptorów GABA lub benzodiazepin (Braley i Chervin 2015).

W tabeli 4 przedstawiono leki najczęściej stosowane w zaburzeniach snu (Braley i Chervin 2015; Gałecki i Szulc 2018; Szczeklik i Gajewski 2019; Colloca i wsp. 2017; Corcos 2017; Wichniak i wsp. 2017). 
Tabela 4. Leczenie stosowane w zaburzeniach snu i przy objawach nasilających zaburzenia snu

\begin{tabular}{|c|c|}
\hline Zaburzenie & Metody terapii \\
\hline RLS & $\begin{array}{l}\text { - redukcja lub odstawienie leków i używek mogących nasilać RLS (antagonistów dopaminy, związków litu, } \\
\text { SSRI, SNRI, leków przeciwhistaminowych, TLPD, alkoholu, nikotyny, kofeiny) } \\
\text { - stosowanie agonistów dopaminy (pramipeksol, ropinirol, rotygotyna) lub gdy niewskazane jest ich } \\
\text { stosowanie, włączenie pregabaliny, gabapentyny lub karbamazepiny } \\
\text { - suplementacja żelaza w przypadku niedokrwistości }\end{array}$ \\
\hline $\begin{array}{l}\text { Obturacyjny bezdech } \\
\text { senny }\end{array}$ & $\begin{array}{l}\text { - zmiana stylu życia, } \\
\text { - CPAP, BIPAP, aparaty wewnątrzustne wysuwające żuchwę, } \\
\text { - leczenie operacyjne (septoplastyka, tonsylektomia, uwulopalatofaryngoplastyka, osteotomia kości } \\
\text { gnykowej) } \\
\text { - wszczepienie stymulatora nerwu podjęzykowego }\end{array}$ \\
\hline Bezsenność & $\begin{array}{l}\text { - odpowiednia higiena snu } \\
\text { - techniki behawioralne i psychologiczne } \\
\text { - niebenzodiazepinowi agoności receptorów GABA (zolpidem, zopiklon, zaleplon) } \\
\text { - leki przeciwdepresyjne (mianseryna, mirtazapina, trazodon) } \\
\text { - leki przeciwpsychotyczne (kwetiapina, olanzapina, chlorprotiksen) } \\
\text { - wyjątkowo beznzodiazepiny (temazepam, estazolam) lub hydroksyzyna }\end{array}$ \\
\hline $\begin{array}{l}\text { Wzmożone napięcie } \\
\text { mięśniowe }\end{array}$ & - leki miorelaksujące (baklofen, tyzanidyna) \\
\hline Depresja & $\begin{array}{l}\text { - SSRI (fluoksetyna, fluwoksamina, citalopram, escitalopram, sertralina, paroksetyna) } \\
\text { - SNRI (wenlafeksyna, duloksetyna) } \\
\text { - inne leki (bupropion, mianseryna, mirtazapina, reboksetyna, trazodon, tianeptyna, agomelatyna, } \\
\text { moklobemid) }\end{array}$ \\
\hline Ból neuropatyczny & $\begin{array}{l}\text { - gabapentyna, pregabalina } \\
\text { - SNRI (duloksetyna, wenlafeksyna) } \\
\text { - TLPD (nortryptylina, dezypramina, amitryptylina, klomipramina i imipramina) } \\
\text { - rzadziej stosowane: plastry z 5-proc. lidokainą, opioidy (tramadol, morfina, oksykodon), toksyna } \\
\text { botulinowa }\end{array}$ \\
\hline $\begin{array}{l}\text { Zaburzenia rytmu } \\
\text { okołodobowego }\end{array}$ & $\begin{array}{l}\text { - melatonina } \\
\text { - fototerapia } \\
\text { - unikanie ekspozycji na światło w zaplanowanych przez lekarza porach dnia }\end{array}$ \\
\hline $\begin{array}{l}\text { Zespół pęcherza } \\
\text { nadreaktywnego }\end{array}$ & $\begin{array}{l}\text { - terapia behawioralna (trening pęcherza oraz mięśni dna miednicy), zmiana stylu życia (ograniczenie } \\
\text { używek, dieta) } \\
\text { - antagoniści receptora } M_{3} \text { (solifenacyna) } \\
\text { - leki cholinoltyczne (oksybutynina) } \\
\text { - wybiórczy agonista receptorów } \beta_{3} \text {-adrenergicznych (mirabegron) }\end{array}$ \\
\hline
\end{tabular}

SSRI - inhibitory wychwytu zwrotnego serotoniny; SNRI - inhibitory wychwytu zwrotnego serotoniny i noradrenaliny; TLPD - trójpierścieniowe leki przeciwdepresyjne; CPAP (continuous positive airway pressure) - stałe dodatnie ciśnienie drogach oddechowych; BIPAP (biphasic positive airway pressure) - dwupoziomowe ciśnienie w płucach

\section{Podsumowanie}

SM, jak każda choroba przewlekła powodująca m.in. niepełnosprawność ruchową, dolegliwości bólowe oraz zaburzenia nastroju, wpływa na jakość i długość snu. $\mathrm{Z}$ jednej strony, $\mathrm{z}$ dotychczas przeprowadzonych badań wynika, że zaburzenia snu w SM mają raczej charakter wtórny i są częściej obserwowane w bardziej zaawansowanych stadiach choroby. Z drugiej strony, zaburzenia snu stanowią problem praktyczny, często nierozpoznawany i nieleczony wystraczająco, a mający duży wpływ na poziom funkcjonowania chorego i jakość życia. Dodatkowo rzadko zwraca się uwagę na występowanie takich zaburzeń, jak obturacyjny bezdech senny lub zespół niespokojnych nóg, które mają tendencje do częstszego występowania u chorych na SM niż w populacji ogólnej. Słaba jakość snu lub niewystarczająca jego długość mogą znacznie zaburzyć codzienne funkcjonowanie chorych, prowadzić do senności w ciągu dnia, zmniejszonej wydajności w pracy, zaburzeń koncentracji, uwagi, pamięci, nasilenia zaburzeń lękowych oraz depresji. Zatem niezmiernie istotna jest odpowiednia ocena chorych pod kątem występowania zaburzeń snu i ich poprawne rozpoznawanie. Chorym powinno zalecać się wyeliminowanie czynników powodujących zaburzenia snu, na które pacjent może mieć bezpośredni wpływ. Należą do nich m.in. drzemki w ciągu dnia, zmienne godziny snu, brak aktywności fizycznej w ciągu dnia lub nadmierne zajęcia ruchowe wymagające nadmiernego wysiłku tuż przed snem, przyjmowanie używek oraz spożywanie ciężkostrawnych potraw przed położeniem się do łóżka. Przestrzeganie właściwej higieny snu i odpowiednia terapia mogą poprawić jakość snu, a także wpływać na szereg zaburzeń towarzyszących, poprawiając tym samym funkcjonowanie chorych z SM. 
Conflict of interest and financial support non declared. / Nie zgłoszono konfliktu interesów oraz dofinansowania.

The work described in this article has been carried out in accordance with The Code of Ethics of the World Medical Association (Declaration of Helsinki) for experiments involving humans, EU Directive 2010/63/EU for animal experiments, and Uniform Requirements for manuscripts submitted to biomedical journals. / Treści przedstawione w artykule są zgodne z zasadami Deklaracji Helsińskiej, dyrektywami EU oraz ujednoliconymi wymaganiami dla czasopism biomedycznych.

Authors' contributions / Wkład autorów: KK - conceptual work, literature search, content of a significant part of the article / projekt artykułu, zaplanowanie artykułu, przegląd piśmiennictwa, treść znacznej części artykułu; IK-J - corrections to the article content, literature search, summaries in some parts of the article / poprawki treści artykułu, przegląd piśmiennictwa, napisanie podsumowania w części rozdziałów; AP - corrections to the article content, literature search, summaries in some parts of the article / poprawki treści artykułu, przegląd piśmiennictwa, napisanie podsumowania w części rozdziałów

\section{References / Piśmiennictwo}

1. Allen RP, Auerbach S, Bahrain H, Auerbach M, Earley CJ. The prevalence and impact of restless legs syndrome on patients with iron deficiency anemia. Am J Hematol 2013; 88(4): 261-4.

2. American Academy of Sleep Medicine. International Classification of Sleep Disorders. 3rd ed. Darien, IL: American Academy of Sleep Medicine 2014.

3. American Psychiatric Association, Diagnostic and Statistical Manual of Mental Disorders DSM-V, American Psychiatric Publishing 2013.

4. Amtmann D, Askew RL, Kim J, Chung H, Ehde DM, Bombardier $\mathrm{CH}$, et al. Pain affects depression through anxiety, fatigue, and sleep in multiple sclerosis. Rehabil Psychol 2015; 60(1): 81-90.

5. Benedict RH, Wahlig E, Bakshi R. Predicting quality of life in multiple sclerosis: accounting for physical disability, fatigue, cognition, mood disorder, personality, and behavior change. J Neurol Sci 2005; 231: 29-34.

6. Bishop M, Rumrill PD. Multiple sclerosis: Etiology, symptoms, incidence and prevalence, and implications for community living and employment. Work 2015; 52(4): 725-734.

7. Bøe LHM, Aae TF, Indrevåg W. Poor sleep in patients with multiple sclerosis. PLoS One 2012; 7(11): e49996.

8. Braley TJ, Boudreau EA. Sleep Disorders in Multiple Sclerosis. Curr Neurol Neurosci Rep 2016; 16(5): 50.

9. Braley TJ, Chervin RD. Fatigue in multiple sclerosis: mechanisms, evaluation, and treatment. Sleep 2010; 33(8): 1061-1067.

10. Braley TJ, Chervin RD. A practical approach to the diagnosis and management of sleep disorders in patients with multiple sclerosis. Ther Adv Neurol Disord 2015; 8(6): 294-31.

11. Braley TJ, Segal BM, Chervin RD. Sleep-disordered breathing in multiple sclerosis. Neurology 2012; 79(9): 929-36.

12. Braley TJ, Segal BM, Chervin RD. Obstructive sleep apnea and fatigue in patients with multiple sclerosis. J Clin Sleep Med 2014; 10(2): 155-62.

13. Braley TJ, Kratz AL, Kaplish N, Chervin RD. Sleep and Cognitive Function in Multiple Sclerosis. Sleep 2016; 39(8): 1525-33.
14. Brass SD, Li CS, Auerbach S. The underdiagnosis of sleep disorders in patients with multiple sclerosis. J Clin Sleep Med 2014; 10(9): 1025-1031.

15. Bruno E, Nicoletti A, Messina S, Lo Fermo S, Raciti L, Quattrocchi $\mathrm{G}$, et al. Restless legs syndrome and multiple sclerosis: a population based case-control study in Catania, Sicily. Eur J Neurol 2015; 22(6): 1018-21.

16. Colloca L, Ludman T, Bouhassira D, Baron R, Dickenson AH, Yarnitsky D, et al. Neuropathic pain. Nat Rev Dis Primers 2017; 3: 17002.

17. Connor JR, Ponnuru P, Lee B-Y, Podskalny GD, Alam S, Allen $\mathrm{RP}$, et al. Postmortem and imaging based analyses reveal CNS decreased myelination in restless legs syndrome. Sleep Med 2011; 12: 614e9.

18. Corcos J, Przydacz M, Campeau L, Gray G, Hickling D, Honeine $\mathrm{C}$, et al. CUA guideline on adult overactive bladder. Can Urol Assoc J 2017; 11(5): E142-E173.

19. Cote I, Trojan D, Kaminska M, Cardoso M, Benedetti A, Weiss D. Impact of sleep disorder treatment on fatigue in multiple sclerosis. Mult Scler 2013; 19: 480-489.

20. Čarnická Z, Kollár B, Šiarnik P, Krížová L, Klobučníková K, Turčáni P. Sleep disorders in patients with multiple sclerosis. J Clin Sleep Med 2015; 11(5): 553-557.

21. Damasceno A, Moraes AS, Farias A, Damasceno BP, dos Santos L, Cendes F. Disruption of melatonin circadian rhythm production is related to multiple sclerosis severity: a preliminary study. J Neurol Sci 2015; 353: 166-168.

22. Farhadi N, Oryan S, Nabiuni M. Serum levels of melatonin and cytokines in multiple sclerosis. Biom J 2014; 37: 90-92.

23. Finan PH, Goodin BR, Smith MT. The Association of Sleep and Pain: An Update and a Path Forward. J Pain 2013; 14(12): 1539-1552.

24. Foschi M, Rizzo G, Liguori R, Avoni P, Mancinelli L, Lugaresi A, et al. Sleep-related disorders and their relationship with MRI findings in multiple sclerosis. Sleep Med 2019; 56: 90-97.

25. Gałecki P, Szulc A. Psychiatria. Edra Urban \& Partner, Wrocław 2018; wyd. 1.

26. Gholipour T, Ghazizadeh T, Babapour S. Decreased urinary level of melatonin as a marker of disease severity in patients with multiple sclerosis. Iran J Allergy Asthma Immunol 2015; 14: 91-97.

27. Heesen C, Nawrath L, Reich C, Bauer N, Schulz KH, Gold SM. Fatigue in multiple sclerosis: an example of cytokine mediated sickness behaviour? J Neurol Neurosurg Psychiatry 2006; 77(1): 34-9.

28. Janardhan V, Bakshi R. Quality of life in patients with multiple sclerosis: the impact of fatigue and depression. J Neurol Sci 2002; 205: 51-58.

29. Kalb R, Beier M, Benedict RH, Charvet L, Costello K, Feinstein A, et al. Recommendations for cognitive screening and management in multiple sclerosis care. Mult Scler 2018; 24(13): 1665-1680.

30. Kaminska M, Kimoff R, Benedetti A, Robinson A, Bar-Or A, Lapierre Y, et al. Obstructive sleep apnea is associated with fatigue in multiple sclerosis. Mult Scler J 2011; 18(8): 1159-1169.

31. Kaminska M, Trojan DA, Kimoff RJ. Association between OSA and severe fatigue in patients with multiple sclerosis (MS). J Clin Sleep Med 2014; 10(6): 707.

32. Kaynak H, Altintaş A, Kaynak D, Uyanik O, Saip S, Ağaoğlu $\mathrm{J}$, et al. Fatigue and sleep disturbance in multiple sclerosis. Eur J Neurol 2006; 13(12): 1333-9.

33. Kuzminska M. Obturacyjny bezdech senny - czy jest problemem ludzi starszych? Post Nauk Med 2011; 54(5): 440-445. 
34. Lee J, Nicholl DDM, Ahmed SB, Loewen AHS, Hemmelgarn $\mathrm{BR}$, Beecroft JM, et al. The prevalence of restless legs syndrome across the full spectrum of kidney disease. J Clin Sleep Med 2013; 9:455e9.

35. Maestri M, Romigi A, Schirru A, Fabbrini M, Gori S, Bonuccell, et al. Excessive daytime sleepiness and fatigue in neurological disorders. Sleep Breath 2019 Aug 23.

36. Manconi M, Fabbrini M, Bonanni E, Filippi M, Rocca M, Murri L, et al. High prevalence of restless legs syndrome in multiple sclerosis. Eur J Neurol 2007; 14:534e9.

37. Manconi M, Govoni V, De Vito A, Economou NT, Cesnik E, Casetta I, et al. Restless legs syndrome and pregnancy. Neurology 2004; 63(6): 1065-9.

38. Morse AM, Kothare SV. Sleep disorders and concussion. Handb Clinic Neurol 2018; 158 127-134.

39. Najafi MR, Toghianifar N, Etemadifar M, Haghighi S, Maghzi $\mathrm{AH}$, Akbari M. Circadian rhythm sleep disorders in patients with multiple sclerosis and its association with fatigue: A case-control study. J Res Med Sci 2013; 18(Suppl 1): S71-3.

40. O'Connor AB, Schwid SR, Herrmann DN, Markman JD, Dworkin RH. Pain associated with multiple sclerosis: systematic review and proposed classification. Pain 2008; 137(1): 96-111.

41. Plywaczewski R, Brzecka A, Bielicki P, Czajkowska-Malinowska M, Cofta S, Jonczak L. Zalecenia Polskiego Towarzystwa Chorób Płuc dotyczące rozpoznawania i leczenia zaburzeń oddychania w czasie snu (ZOCS) u dorosłych. Pneumonol Alergol Pol 2013; 81(3): 221-258.

42. Sadeghi Bahmani D, Kesselring J, Papadimitriou M, Bansi J, Pühse U, Gerber M, et al. In Patients With Multiple Sclerosis, Both Objective and Subjective Sleep, Depression, Fatigue, and Paresthesia Improved After 3 Weeks of Regular Exercise. Front Psychiatry 2019; 10: 265.

43. Sakkas GK, Giannaki CD, Karatzaferi C, Manconi M. Sleep Abnormalities in Multiple Sclerosis. Curr Treat Options Neurol 2019; 21(1): 4.

44. Sateia MJ. International classification of sleep disorders-third edition: highlights and modifications. Chest 2014; 146(5): 1387-1394.

45. Sater RA, Gudesblatt M, Kresa-Reahl K, Brandes DW, Sater PA. The relationship between objective parameters of sleep and measures of fatigue, depression, and cognition in multiple sclerosis. Mult Scler J Exp Transl Clin 2015; 1: 2055217315577828.

46. Sieminski M, Losy J, Partinen M. Restless legs syndrome in multiple sclerosis. Sleep Med Rev 2015; 22: 15-22.

47. Simpson L, Hillman DR, Cooper MN, Ward KL, Hunter M, Cullen S, et al. High prevalence of undiagnosed obstructive sleep apnoea in the general population and methods for screening for representative controls. Sleep Breath 2013; 17(3): 967-73.

48. Skarlis C, Anagnostouli M. The role of melatonin in Multiple Sclerosis. Neurol Sci 2019 Dec 16.
49. Stanton BR, Barnes F, Silber E. Sleep and fatigue in multiple sclerosis. Mult Scler 2006; 12(4): 481-6.

50. Steiger A, Pawlowski M. Depression and Sleep. Int J Mol Sci 2019; 20(3), pii:E607.

51. Stenager E, Knudsen L, Jensen K. Acute and chronic pain syndromes in multiple sclerosis. A 5-year follow-up study. Ital J Neurol Sci 1995; 16(9): 629-32.

52. Szczeklik A, Gajewski A. Interna Szczeklika. MP, Kraków 2019, wyd. 10.

53. Tachibana N, Howard RS, Hirsch NP, Miller DH, Moseley IF, Fish D. Sleep problems in multiple sclerosis. Eur Neurol 1994; 34(6): 320-3.

54. Taphoorn MJ, van Someren E, Snoek FJ, Strijers RL, Swaab DF, Visscher F, et al. Fatigue, sleep disturbances and circadian rhythm in multiple sclerosis. J Neurol 1993; 240(7): 446-8.

55. Thorpy MJ. Classification of sleep disorders. Neurotherapeutics. 2012; 9(4): 687-701.

56. Tonetti L, Camilli F, Giovagnoli S, Natale V, Lugaresi A. Circadian Activity Rhythm in Early Relapsing-Remitting Multiple Sclerosis. J Clin Med 2019; 8(12), pii:E2216.

57. Veauthier C. Sleep Disorders in Multiple Sclerosis. Review. Curr Neurol Neurosci Rep 2015; 15(5): 21.

58. Veauthier C, Radbruch H, Gaede G, Pfueller CF, Dörr J, Bellmann-Strobl J, et al. Fatigue in multiple sclerosis is closely related to sleep disorders: a polysomnographic cross-sectional study. Mult Scler 2011; 17(5): 613-22.

59. Vega R, Miró J, Esteve R, Ramírez-Maestre C, López-Martínez AE, Jensen MP. Sleep disturbance in individuals with physical disabilities and chronic pain: The role of physical, emotional and cognitive factors. Disabil Health J 2019; 12 (4): 588-593.

60. Vitkova M, Gdovinova Z, Rosenberger J, Szilasiova J, Nagyová I, Mikula P, et al. Factors associated with poor sleep quality in patients with multiple sclerosis differ by disease duration. Disabil Health J 2014; 7(4): 466-71.

61. Wichniak A, Jankowski KS, Skalski M, Skwarło-Sońta K, Zawilska JB, Żarowski M, et al. Standardy leczenia zaburzeń rytmu okołodobowego snu i czuwania opracowane przez Polskie Towarzystwo Badań nad Snem i Sekcję Psychiatrii Biologicznej Polskiego Towarzystwa Psychiatrycznego. Część I. Fizjologia, metody oceny i oddziaływania terapeutyczne. Psychiatr Pol 2017; 61: 1-22.

62. Wojtas A, Ciszewski S. Epidemiologia bezsenności. Psychiatria 2011; 8(3): 79-83.

63. World Health Organization. Classification of diseases (ICD) 2018. http://www.who.int/classifications/icd/en/

64. Wright LJ. Identifying and treating pain caused by MS. J Clin Psychiatry 2012; 73(7): e23.

65. Young T, Palta M, Dempsey J, Skatrud J, Weber S, Badr S. The occurrence of sleep- disordered breathing among middle-aged adults. N Engl J Med 1993; 328(17): 1230-1235. 